American University Washington College of Law

Digital Commons @ American University Washington College of

Law

Articles in Law Reviews \& Other Academic Journals

Scholarship \& Research

2016

Overlapping Financial Investor Ownership, Market Power, and Antitrust Enforcement: My Qualified Agreement with Professor Elhauge

Jonathan Baker

Follow this and additional works at: https://digitalcommons.wcl.american.edu/facsch_lawrev

Part of the Antitrust and Trade Regulation Commons, Business Organizations Law Commons, and the Law and Economics Commons 


\title{
OVERLAPPING FINANCIAL INVESTOR OWNERSHIP, MARKET POWER, AND ANTITRUST ENFORCEMENT: MY QUALIFIED AGREEMENT WITH PROFESSOR ELHAUGE
}

\author{
Jonathan B. Baker*
}

More than a century ago, a loophole in the antitrust laws helped trigger a giant wave of industrial consolidation, ${ }^{1}$ by which rival manufacturing firms in one industry after another combined into a single large enterprise that controlled industry prices. ${ }^{2}$ The loophole was closed, ${ }^{3}$ but not before the industrial landscape had been transformed to allow the widespread exercise of market power. ${ }^{4}$ A recent working paper by economists José Azar, Martin Schmalz, and Isabel Tecu raises the possibility that a modern-day antitrust loophole or blind spot has similarly been allowing firms to exercise market power across the economy. ${ }^{5}$

As is well known among financial economists but not previously recognized within the antitrust community, large and diversified institutional investors such as BlackRock, Fidelity, State Street, and Vanguard collectively own roughly two-thirds of the shares of publicly traded U.S. firms overall, up from about one-third in $1980 .{ }^{6}$ Moreover,

* Professor of Law, American University Washington College of Law. The author is grateful to José Azar, Benjamin Leff, Einer Elhauge, Andrew Gavil, Robert G. Hansen, Steven Salop, and Martin Schmalz.

1 The loophole was created by the Supreme Court's decision in United States v. E.C. Knight Co., I56 U.S. I (I895), which allowed mergers to create a monopoly in sugar refining on the ground that the Sherman Act's prohibitions on restraints or monopolization of "commerce" concerned the disposition of manufactured goods, not the prior manufacturing step, see id. at I4.

2 See generally NaOmi R. Lamoreaux, The Great Merger Movement iN AMERICAN BUSINESS, I895-I904 (I985) (documenting the wave of manufacturing mergers occurring after the Supreme Court's decision in E.C. Knight).

3 Addyston Pipe \& Steel Co. v. United States, I75 U.S. 2 I I (I899) (effectively limiting the holding in E.C. Knight to that decision's facts); N. Sec. Co. v. United States, I93 U.S. I97 (I904) (affirming the application of the antitrust laws to prohibit anticompetitive mergers).

4 Firms exercise market power, individually or collectively, by reducing output to raise price. The exercise of market power often allows firms to set prices at higher-than-competitive levels, but not always. See Jonathan B. Baker, Competitive Price Discrimination: The Exercise of Market Power Without Anticompetitive Effects, 70 ANTITRUST L.J. 643, 65 I (2003).

5 José Azar, Martin C. Schmalz \& Isabel Tecu, Anti-Competitive Effects of Common Ownership (Ross Sch. of Bus., Working Paper No. I2 35, 2015), http:/ssrn.com/abstract=242 7345 [http:// perma.cc/FLN $2-75 \mathrm{VQ}]$. Whether the problem is a loophole or merely an enforcement blind spot depends on the significance of the enforcement difficulties discussed below in Part III.

6 Marshall E. Blume \& Donald B. Keim, The Changing Nature of Institutional Stock Investing 5 (Nov. I2, 20I4) (unpublished manuscript), https://fnce.wharton.upenn.edu/profile/948 /research [http://perma.cc/KT9A-8DBM]; see THE CONFERENCE BOARD, THE 20 Io INSTITUTIONAL INVESTMENT REPORT 22 tbl. Io (20I0), http://ssrn.com/abstract $=17075$ I 2 [http://perma .cc/L5 XM-59Q4] (describing how institutional ownership of U.S. equities rose from $28.4 \%$ in 1980 
financial investors have overlapping ownership interests in a substantial fraction of the equity of rival firms in a wide range of major industries, including airlines, banks, retail pharmacies, and technology firms. ${ }^{7}$ For example, BlackRock owns $5.9 \%$ of the equity in CVS, a pharmacy chain, and $4.44 \%$ of the equity in Walgreens, a rival pharmacy chain. ${ }^{8}$ Azar, Schmalz, and Tecu's empirical study finds that as a result of overlapping financial investor ownership of major air carriers, airfares are $3 \%$ to I $\%$ higher $^{9}$ and the number of airline passengers $6 \%$ lower ${ }^{10}$ than they would be otherwise.

These preliminary results raise the possibility that overlapping ownership of horizontal rivals by diversified financial institutions facilitates anticompetitive conduct throughout the economy, and that the problem has been growing for decades, unnoticed until now. ${ }^{11}$ In his article Horizontal Shareholding, ${ }^{12}$ Professor Einer Elhauge dates the problem from around $1980 .{ }^{13}$ He contends that eliminating overlapping financial investor ownership will increase economic growth and employment, and reduce income inequality. ${ }^{14} \mathrm{He}$ also argues that the problem can readily be solved through antitrust enforcement under the Clayton Act. ${ }^{15}$

My overall reaction to what Elhauge asserts is "yes, but." As I will explain in Part I, market power has been growing, and the increase in overlapping financial investor ownership may well be an important cause, but we do not know how much that increase matters. As I will discuss in Part II, increased antitrust enforcement will be beneficial but not in the direct and immediate macroeconomic way that Elhauge supposes. In addition, I will explain in Part III why it may be more difficult to address overlapping financial investor ownership under the

to $50.6 \%$ in 2009); id. at 27 tbl. 13 (noting that institutions owned $73.0 \%$ of the equity in the top $\mathrm{I}, 000$ corporations in 2009).

7 Azar, Schmalz \& Tecu, supra note 5, at $\mathrm{I}_{4}, 48$ tbl.I.

8 See id. at 48 tbl. I. In addition, Fidelity, State Street, and Vanguard each own $3-5 \%$ of the stock of both firms. Id. These ownership shares predate Walgreens's proposed acquisition of Rite Aid, a third pharmacy chain. See Dana Mattioli, Michael Siconolfi \& Dana Cimilluca, Walgreens, Rite Aid Unite to Create Drugstore Giant, WALL ST. J. (Oct. 27, 2015, 9:01 PM), $\mathrm{http} / /$ www.wsj.com/articles/walgreens-boots-alliance-nears-deal-to-buy-rite-aid-I 445964090.

9 Azar, Schmalz \& Tecu, supra note 5, at 37.

10 Id. at 27 .

11 I prefer to summarize the phenomenon with the term "overlapping financial investor ownership" rather than "horizontal shareholdings," Professor Einer Elhauge's term, to make clear that the problem is not with industrial firms owning shares in each other.

12 Einer Elhauge, Horizontal Shareholding, I29 HARV. L. REV. I 267 (2016).

13 More precisely, Elhauge observes that both overlapping financial ownership and increased economic inequality have grown since $\mathrm{Ig} 8 \mathrm{O}$, attributes the increase in inequality in part to increased market power, and suggests that the increase in market power is related to greater overlapping financial investor ownership. $I d$. at $\mathrm{I} 29 \mathrm{I}-92$.

14 Id at $\mathrm{I} 300-\mathrm{O}$.

15 Id. at $\mathrm{I} 302$. 
antitrust laws than Elhauge recognizes. I suspect Elhauge is right about the significance of overlapping financial investor ownership, and his proposed antitrust remedy could turn out to be effective, but as of today these are open questions.

\section{OVERLAPPING FINANCIAL INVESTOR OWNERSHIP AND MARKET POWER}

The exercise of market power has almost surely been on the rise in the U.S. economy since I980. The increase in overlapping financial investor ownership is one of several plausible contributing factors.

One reason market power has been growing is the Supreme Court's thoroughgoing transformation of antitrust rules, which began during the mid-I970s, along lines suggested by Chicago-School commentators. ${ }^{16}$ The new rules addressed the Chicago concern that the prior rules had a chilling effect on firms seeking to reduce costs and achieve other production efficiencies. ${ }^{17}$ But the new rules also systematically accepted a greater risk of false negatives, increasing the likelihood that firms would exercise market power undeterred by the antitrust laws. Not surprisingly, retrospective studies of merger enforcement find that today the marginal horizontal merger - the close case that government enforcers decide not to challenge - likely harms competition. ${ }^{18}$

The airline industry illustrates the modern limits of antitrust rules and enforcement in deterring anticompetitive conduct. The industry

16 See Jonathan B. Baker, A Preface to Post-Chicago Antitnust, in Post-ChICAgo Developments in Antitrust LaW 60, 65-67 (Antonio Cucinotta, Roberto Pardolesi \& Roger Van den Bergh eds., 2002).

17 Even critics from the left were persuaded that some reforms were needed. See, e.g., Robert Pitofsky, Does Antitrust Have a Future?, 76 GEO. L.J. 32 I, 323-25 (1987) (finding "much wrong with the overly active antitrust enforcement policies of the r 960 ," $i d$. at $323-24$, and commending the Supreme Court for moving "cautiously and thoughtfully in the direction of more lenient antitrust policies," $i d$. at 325 , since the mid-rg7os through decisions that were "generally more solicitous toward claims of efficiency," $i d$.). But those critics have consistently resisted the Chicago reformation of rules governing exclusionary conduct. See, e.g., Steven C. Salop, Economic Analysis of Exchisionary Vertical Conduct: Where Chicago Has Overshot the Mark, in How THE Chicago School Overshot THE MARK I4I, I4I-44 (Robert Pitofsky ed., 2008).

18 See John Kwoka, Mergers, Merger Control, And Remedies 86, 94 (20 15); Orley Ashenfelter \& Daniel Hosken, The Effect of Mergers on Consumer Prices: Evidence from Five Mergers on the Enforcement Margin, 53 J.L. \& ECON. 4I7, 4I7-I8 (2010). Under the influence of mainstream developments in economics, the government's horizontal merger guidelines and court merger decisions have, over time, reduced the threshold levels of market concentration at which mergers are closely scrutinized and demanded an increasingly detailed economic analysis of proposed acquisitions. The cited economic research indicates that in applying this approach, the agencies have become too solicitous in their merger review. This problem was particularly acute at the Justice Department during the second term of the Reagan administration and the first term of the George W. Bush administration. See Jonathan B. Baker \& Carl Shapiro, Reinvigorating Horizontal Merger Enforcement, in HOW THE CHICAGO SCHOOL OveRsHOT THE MARK, supra note 17 , at $235,244-46$. 
was prone to coordination more than a decade ago, when it had at least seven national network carriers; ${ }^{19}$ economic studies have found that multimarket contact among the airlines has facilitated coordinated conduct; ${ }^{20}$ and incumbent network carriers likely engaged in predatory conduct to discourage competition from upstart rivals in routes to and from their hub airports. ${ }^{21}$ Yet the government permitted further industry consolidation that has left the industry with only three national network carriers (American, Delta, and United) that collectively account for most airline passengers, especially for business travel; a large so-called "low-cost airline" (Southwest); and several substantially smaller low-cost airlines. ${ }^{22}$

The Justice Department challenged the most recent airline deal, the merger between American and U.S. Airways, but it ended up accepting a settlement that allowed the merger to proceed. The settlement did not directly address the competitive problems with coordinated conduct in the city-pair markets where, the government alleged, the merger would eliminate discount fares. ${ }^{23}$ After a decade of industry

19 See Jonathan B. Baker, Mavericks, Mergers, and Exclusion: Proving Coordinated Competitive Effects Under the Antitrust Laws, 77 N.Y.U. L. REV. I35, I66-73 (2002); Proposed Final Judgment and Competitive Impact Statement, United States v. Airline Tariff Publ'g Co., 59 Fed. Reg. I5,225 (Mar. 3I, I994); Proposed Final Judgment and Competitive Impact Statement, United States v. Airline Tariff Publ'g Co., 58 Fed. Reg. 3,97 I (Jan. I2, I993).

${ }^{20}$ Federico Ciliberto \& Jonathan W. Williams, Does Multimarket Contact Facilitate Tacit Collusion? Inference on Conduct Parameters in the Airline Industry, 45 RAND J. ECON. 764, 765, 789 (2014); William N. Evans \& Ioannis N. Kessides, Living by the "Golden Rule": Multimarket Contact in the U.S. Airline Industry, Io9 Q. J. ECON. 34 I, 365 (I994).

21 Jonathan W. Williams, Capacity Investments, Exclusionary Behavior, and Welfare: A Dynamic Model of Competition in the Airline Industry 29 (Jan. I6, 2013) (unpublished manuscript), http://ssrn.com/abstract= ${ }_{3} 375450$ [http://perma.cc/NMM ${ }_{4-3} \mathrm{QHU}$ ] (presenting empirical evidence that the incumbent carrier conduct deterred entry and led to higher prices). A r 999 study by the Transportation Research Board of the National Research Council of the National Academy of Sciences, in which I participated, expressed concern about the competitive significance of incumbent carrier conduct but did not reach a firm conclusion. TRANSP. RESEARCH BD., NAT'L RESEARCH COUNCIL, SPECIAL REPORT 255: ENTRY AND COMPETITION IN THE U.S. AIRLINE INDUSTRY 97 (1999) (finding that in some cases, incumbent airlines "added nonstop service in low- to moderate-density markets they had not previously served directly, coincident with a new entry," and that "the incumbent bypassed its own hub to initiate the service, a strategy seldom employed outside of high-density markets," and that "[t]he logical inference is that such responses are probably temporary - possibly calculated to protect the incumbent's hub traffic and to dissuade similar challenges elsewhere - and would seem to warrant additional scrutiny").

22 When deciding not to challenge network-carrier mergers, the government has accepted merging firm arguments that the production efficiency benefits of combining complementary route networks outweighed the risk of market power. Press Release, Dep't of Justice, Statement of the Department of Justice's Antitrust Division on Its Decision to Close Its Investigation of the Merger of Delta Air Lines Inc. and Northwest Airlines Corporation (Oct. 29, 2008), http://www .justice.gov/archive/atr/public/press_releases/2008/238849.pdf [http://perma.cc/5GPL-JQD4].

23 Cf. Response of Plaintiff United States to Public Comments on the Proposed Final Judgment at 27, 32, United States of America v. U.S. Airways Group, Inc., 38 F. Supp. 3 d 69 (D.D.C. 20I4) (No. I:I3-CV-OI 236) (rejecting views of commentators that "emphasize that the remedy does not provide for the continuation of US Airways's Advantage Fare program or address each city- 
consolidation it was apparently too late for that. Instead, the Justice Department threw a "Hail Mary" pass: it attempted to support the growth of small low-cost airline rivals to the large hub carriers by requiring the merged firm to sell gates or takeoff and landing slots at seven major airports. ${ }^{24}$ That approach is a long shot in part because the fringe firms are not the competitive force they would have been absent the Chicago-influenced modifications to antitrust rules. These rules proved to be an insurmountable hurdle to an earlier government challenge to exclusionary conduct by a large network carrier that harmed low-cost airline competition. ${ }^{25}$

The contemporary problem of market power is not just the consequence of changes in antitrust rules that have reduced deterrence. Indeed, many likely sources of market power today do not necessarily violate the antitrust laws. Technological change has created more markets in which firms benefit from intellectual property protection or network effects. ${ }^{26}$ Many large information technology firms in network industries created since I980 - perhaps including Bloomberg, Facebook, Google, Microsoft, and Oracle - likely exercise market power in some of their major markets for these reasons. ${ }^{27}$ In addition, the U.S. political process increasingly responds disproportionately to

pair route in which American and US Airways provided competing service," id. at 27 , while acknowledging that the remedy "does not seek to precisely match harm on a route-by-route basis," id. at 32 ).

24 Proposed Final Judgment and Competitive Impact Statement, United States et al. v. U.S. Airways Group, Inc. and AMR Corporation, 78 Fed. Reg. 71,378, 71,396 (Nov. 27, 2013).

25 See United States v. AMR Corp., 335 F.3d I Io9 (Ioth Cir. 2003) (upholding summary judgment in favor of the hub carrier). But cf. Spirit Airlines, Inc. v. Nw. Airlines, Inc., 43I F.3d 9I 7 (6th Cir. 2005) (reversing grant of summary judgment in favor of the hub carrier because factual disputes remained). The modern test for predatory pricing derives from a proposal by Professors Phillip Areeda and Donald Turner that courts presume that a monopolist acts unlawfully by setting a price below its average variable cost. Phillip Areeda \& Donald F. Turner, Predatory Pricing and Related Practices Under Section 2 of the Sherman Act, 88 HARV. L. REv. 697, 7I2-I3 (1975). In implementation by the Chicago-oriented courts, the test was flipped to presume lawful a monopolist's price above average variable cost.

${ }^{26}$ See Dean Baker, The Upward Redistribution of Income: Are Rents the Story? 5-8 (Ctr. for Econ. \& Pol'y Research, Working Paper 20I5), http://cepr.net/documents/working-paper-upward -distribution-income-rents.pdf [http://perma.cc/7VA 3 -UA8C] (estimating value of rents from patent and copyright monopolies and indicating that a large share of those rents goes to the wealthy); cf. Dongya Koh, Raül Santaeulàlia-Llopis \& Yu Zheng, Labor Share Decline and the Capitalization of Intellectual Property Products (Apr. 2015) (unpublished manuscript), https://www.aeaweb .org/aea/2or6conference/program/retrieve.php?pdfid=392 [http://perma.cc/7GL6-CNTU] (documenting the increasing importance of intellectual property capital in the U.S. economy since the mid-2oth century). Intellectual property protections grew as a result of legislation, including the creation of the Federal Circuit, and judicial decisions that increased the scope and length of intellectual property rights.

27 To the best of my knowledge, Microsoft is the only firm among those listed that has been found by U.S. courts to have violated the antitrust laws. See United States v. Microsoft Corp., 253 F.3d 34 (D.C. Cir. 200I). 
the concerns of the wealthy; 28 those concerns may include protecting firms that are sources of existing wealth from new competition.

The recent economic research by Azar, Schmalz, and Tecu points to the possibility that the growth in overlapping financial investor ownership since r 980 has been an important additional source of market power. ${ }^{29}$ Some increase in market power would be expected: overlapping financial investor ownership has increased greatly and economic theory predicts it will lead to higher prices. ${ }^{30}$ Along with Elhauge, I suspect that the economy-wide consequences for the exercise of market power have been substantial. But the magnitude and scope of the problem in the economy as a whole have not been fully established in the economic literature. The empirical analysis in the airline study is careful, but the study is unpublished; two of the study's authors have extended it to only one industry beyond airlines (banking); ${ }^{31}$ and other researchers have not yet attempted to replicate its results for those industries or for other industries with significant overlapping ownership by financial investors. In addition, the airline and banking studies do not account for the potentially countervailing impact of financial investors' ownership interests in inputs, complementary products, and customers, or for the potentially countervailing impact of vertical integration by the firms into complementary lines of business. ${ }^{32}$

Further research will also be needed to identify the mechanisms through which overlapping financial investor ownership leads firms to raise product prices. Do the financial investors facilitate tacit or express coordination through communications with firm executives? Do the firms simply observe and take into account the overlapping finan-

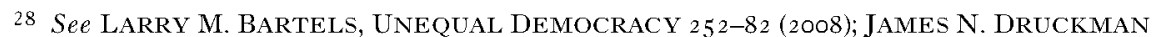
\& LAWRENCE R. JACOBS, Who Governs? I24-25 (2015); MARTIN GILENS, AFFluence \& Influence 85 (2012); JefFrey A. Winters, Oligarchy 249 (20II); Martin Gilens \& Benjamin I. Page, Testing Theories of American Politics: Elites, Interest Groups, and Average Citizens, I 2 PERSP. ON POL. 564, 576 (20I4).

${ }^{29}$ Antitrust enforcers recognize that if a firm owns a partial ownership stake in a rival, the competitive incentives of each would be muted. E.g., Plaintiff United States of America's Memorandum in Opposition to Defendant Northwest Airlines' Motion for Summary Judgment at I II3, United States v. Nw. Airlines Corp., No. 98-CV-746 I I (E.D. Mich. July 28, 2000). The new question is whether overlapping financial investor ownership, which is closely related, would have similar adverse effects on competition.

30 See generally Daniel P. O'Brien \& Steven C. Salop, Competitive Effects of Partial Ownership: Financial Interest and Corporate Control, 67 ANTITRUST L.J. 559 (2000) (discussing the consequences for market power of the partial ownership of firms by their horizontal rivals).

31 See José Azar, Sahil Raina \& Martin Schmalz, Ultimate Ownership and Bank Competition (Jan. I7, 2016) (unpublished manuscript), http://ssrn.com/abstract $=2710252$ [http://perma.cc $16 \mathrm{~W}_{7} \mathrm{C}_{-\mathrm{ZT}} \mathrm{Z}_{8}$ ] (concluding that greater overlapping financial investor ownership leads to higher interest rate spreads on certificates of deposit and checking accounts and higher bank account maintenance fees).

32 See generally John Woodbury, Paper Trail: Working Papers and Recent Scholarship, I4 ANTITRUST SOURCE, Dec. 2014 (commenting on Azar, Schmalz and Tecu's airline paper). 
cial interests of their major shareholders when making price and output decisions?33 Do they also decide not to take steps to compete with rivals not also owned by their major investors, or to exclude those rivals?

Elhauge's article is predicated on the plausible assumption that continuing economic research will find that overlapping financial investor ownership is the source of substantial market power in industry after industry. But, as I will discuss further in Part III, he is more confident than I am that in antitrust litigation today, a court would be willing to conclude that the problem likely arises in industries not yet studied by economists.

\section{Market Power, Antitrust Enforcement, AND MACROECONOMICS}

Elhauge seconds Professor Steven Salop's and my previously expressed view that market power is one of the plausible causes of the increase in U.S. inequality over the past thirty-five years, and that antitrust enforcement could help address the problem. ${ }^{34}$ He also adopts Professor Paul Krugman's view that the exercise of market power could explain the combination of high corporate profits and sluggish corporate investment during the current recovery. ${ }^{35}$ Elhauge emphasizes the possibility that overlapping financial investor ownership explains these trends in inequality and investment, though he also acknowledges the potential contribution of other factors. ${ }^{36}$

Market power cannot be the full story with investment. Depressed corporate investment since the June 2009 recession trough to a sub-

33 This is the mechanism discussed in O'Brien \& Salop, supra note 3 o. Cf. Ian R. Appel, Todd A. Gormley \& Donald B. Keim, Passive Investors, Not Passive Owners, J. FIN. ECON. (forthcoming), http://ssrn.com/abstract $=2475 \mathrm{I} 50\left[\mathrm{http}: / /\right.$ perma.cc/6 $\left.\mathrm{PR}_{2}-\mathrm{Z}_{3} \mathrm{SZ}\right]$ (passive institutional investors exert influence on managers through their large voting blocs).

34 See generally Jonathan B. Baker \& Steven C. Salop, Antitrust, Competition Policy, and Inequality, IO4 GEO. L.J. ONLINE I (2015). Other factors contributing to increased inequality may include globalization, technological change, a less hospitable regulatory climate for labor unions, erosion in the purchasing power of the minimum wage, changes in corporate governance that raised compensation packages for top executives, and decreased collection of federal estate taxes.

35 See Paul Krugman, The Profits-Investment Disconnect, N.Y. TIMEs (Oct. 24, 20I4, II:4 I AM), http://krugman.blogs.nytimes.com/2O I $4 / \mathrm{IO}_{2} / 2 /$ the-profits-investment-disconnect/ [http:// perma.cc/DCJ 7 -SUKJ]. Krugman had identified a similar divergence between investments and profits before the Great Recession, which he then attributed to managers feathering their own nests at the expense of shareholders rather than to market power. See Paul Krugman, Another Economic Disconnect, N.Y. TMMEs (April 30, 2007), http://www.nytimes.com/2007/04/30/opinion /3okrugman.html.

36 In addition to his analyses of inequality and investment, Elhague connects overlapping financial ownership with corporate pay structures that reward top executives for industry success unrelated to individual firm performance. I do not discuss that possible connection in this response. 
stantial extent is likely the product of macroeconomic conditions unrelated to the exercise of market power: for example, limited sales prospects during a sluggish recovery. ${ }^{37}$ Moreover, the growth in market power (which Elhauge dates from around 1980) likely began well before the observed divergence between profits and investment, which began around 2000 by one measure and around 2008 by another. ${ }^{38}$ It is possible that market power contributed to the current investment slowdown, ${ }^{39}$ but its importance relative to other factors has not been established. Even if greater market power is a substantial cause of depressed investment, moreover, that market power may not have de-

37 Another possible explanation for slowed corporate investment also unrelated to the exercise of market power, which I find less plausible, is that firms with substantial cash hoards are delaying investments because they are awaiting more information about the likely nature of technological change. See Adam Davidson, Why Are Corporations Hoarding Trillions?, N.Y. TIMEs (Jan. $20,2016), \mathrm{http} / / \mathrm{www}$.nytimes.com/20I6/OI/24/magazine/why-are-corporations-hoarding-trillions .html.

38 Real corporate profits grew rapidly from I 960 through 2006, consistent with Elhauge's view that market power has been increasing for decades. (However, the profit rate - return on invested capital - for the top ro\% of firms in profitability did not begin to grow relative to the profit rate for most firms until around 2000.) In the post-I96o data, the growth in real gross private domestic investment slowed relative to the growth in real corporate profits beginning around 2000 . When cyclical variation is accounted for, the divergence appears to begin later in that decade: the post-2006 profits trough was reached a year earlier than the corresponding investment trough, and profits rebounded back to their 2006 level two years earlier than investment. When profits and investment are compared using shares of gross domestic income and gross domestic product, the relative slow growth in investment is a post-2008 phenomenon (reversing a more rapid relative growth in investment from 2006 to 2008 ).

To analyze relative trends in profits and investment, I computed real after-tax corporate profits and compared it with real gross private domestic investment, and compared the relevant shares of gross domestic income and gross domestic product, using the following data series downloaded from Federal Reserve Economic Data (FRED), https://research.stlouisfed.org/fred2 [http://perma.cc/XFR5-LWDK]: Corporate profits after tax (Ao55RCoA ${ }_{44}{ }_{4} \mathrm{NBA}$ ); Producer Price Index for All Commodities (PPIACO); Real Gross Private Domestic Investment (GPDICI); Shares of gross domestic product: Gross private domestic investment: Fixed investment: Nonresidential (Aoo8RErQr56NBEa); and Shares of gross domestic income: Corporate profits with inventory valuation and capital consumption adjustments, domestic industries: Profits after tax with inventory valuation and capital consumption adjustments (W273RE $\mathrm{H}_{15} \mathrm{I}_{6 \mathrm{NBEA}}$ ). Profit rates for firms' profitability deciles are analyzed in Jason Furman \& Peter Orszag, Presentation at "A Just Society" Centennial Event in Honor of Joseph Stiglitz at Columbia University: A FirmLevel Perspective on the Role of Rents in the Rise of Inequality (Oct. I6, 2015).

39 It is also possible that the inverse relationship between market power and investment that Elhauge postulates is nonlinear, and thus that the growth in market power arising from overlapping financial investor ownership did not markedly discourage investment until overlapping financial investor ownership crossed a critical threshold. One might learn more about whether the post-2000 stagnation in business investment is related to market power by studying whether firms in industries with substantial overlapping financial investor ownership have higher profits than most, whether those firms reduced their investment rates around 2000 , and whether their investment shortfall accounts for the lion's share of the shortfall in aggregate corporate investment relative to the pre-20oo trend. (Although the profit rate for the top Io\% of firms in profitability leaped upward around 2000 , the firms in that decile may or may not bear primary responsibility for an overall investment slowdown.) 
rived from only the consequences of overlapping financial investor ownership. It could also or instead have resulted from other forms of exclusionary and collusive conduct undeterred by the antitrust laws, or from intellectual property rights and network effects.

To make plausible a direct connection between market power and overall business investment, Elhauge attributes observable trends in other macroeconomic measures during the economic expansion of the late r930s - particularly trends in inflation and U.S. industrial output - to increased antitrust enforcement during the same years. I do not find this argument persuasive.

I agree with Elhauge that changes in antitrust enforcement regimes can have far-reaching economic impacts. Informal U.S. experiments with little or no antitrust enforcement demonstrate that without enforcement, firms can and do exercise market power, creating substantial and long-lasting harms. ${ }^{40}$ These include the period of ineffectual federal antitrust enforcement during the late nineteenth and early twentieth century and the experience during the early r 930 os under the National Industrial Recovery Act, ${ }^{41}$ which allowed firms to agree industry-wide on how to compete, free of antitrust prohibitions. ${ }^{42}$

In I 938, as Elhauge observes, U.S. antitrust enforcement embarked on a major regime shift. Antitrust's structural era began to take shape with the work of the Temporary National Economic Committee (I938 to I940) and the enforcement efforts of Thurman Arnold during his tenure as Assistant Attorney General for Antitrust (I938 to I943). ${ }^{43}$ But the change in the enforcement regime did not take place overnight. It was not fully established for more than a decade, until it was ratified by the courts, particularly in the United States $v$. SoconyVacuum Oil Co. ${ }^{44}$ (1940) and United States v. Aluminum Co. of America $(\text { Alcoa })^{45}$ (I945) decisions, and ratified by Congress with the CellarKefauver amendments ${ }^{46}$ ( 1950 ) to the Clayton Antitrust Act. ${ }^{47}$

The shift in enforcement regime was associated with the development of an informal national understanding about the role of large firms in the economy - what I have termed a political bargain - un-

\footnotetext{
40 Jonathan B. Baker, The Case for Antitrust Enforcement, I7 J. ECON. PERsP. 27, 36-38 $(2003)$.

41 Pub. L. No. 73-67, 48 Stat. I 95 (I 933 ).

42 Baker, supra note 40 , at $3^{6-37}$. The informal experiments also include the repeal of antitrust laws as they apply to export cartels and the Department of Transportation's lax enforcement against airline mergers during the r 980 s. See id. at $37-38$.

43 I demarcate three major eras of antitrust interpretation: classical, structural, and Chicago School. Baker, supra note 16 , at 60-67. The shift to the Chicago School era began during the late I970s. Id. at 65 .

443 Io U.S. I50 (I940).

45 I48 F.2d 4I6 (2d Cir. 1945).

46 Pub. L. No. 8I-899, 64 Stat. I 25 (I950).

47 Pub. L. No. 63-2I2, 38 Stat. 730 (I9I4).
} 
der which large firms would in general be kept free from economic regulation other than antitrust enforcement. ${ }^{48}$ This microeconomic policy framework generally allowed firms to capture scale economies while limiting their exercise of market power. It was undoubtedly one important reason for economic prosperity and growth in the decades that followed, and it would not be surprising if aggregate output and growth economy-wide were higher over the past seventy-five years than they would have been had such an informal national understanding not emerged during the I940s.

Elhauge does not view the change in regulatory regime as a process lasting at least a decade. Instead he treats it as a sharp political shock largely occurring over a few months during mid-I938. During those months, Assistant Attorney General Arnold and President Franklin Roosevelt gave speeches signaling increased antitrust enforcement, and the Justice Department began to initiate a series of industry-wide antitrust suits. Elhauge attributes key features of the I938 economic recovery to a shift in business expectations resulting from this shock.

I am not convinced, for two reasons. First, businesses could not reasonably have concluded that the change in competition policy introduced in I938, however dramatic, would be long-lasting, given that the antitrust laws had been effectively neutered even more dramatically only five years before. ${ }^{49}$ It would take more than a decade for all aspects of the new antitrust regime to fall into place and for new expectations to solidify. ${ }^{50}$ As a result, the bulk of the deterrent effect of

48 The consumer interests on the left had favored more interventionist and redistributive regulatory and national planning approaches, while the producer interests on the right had favored less interventionist laissez-faire and industry self-regulation approaches that would have tolerated a greater exercise of market power. An informal bargain between these interest groups adopted a centrist approach that allowed the economy to achieve greater efficiencies than were available from either alternative. See Jonathan B. Baker, Competition Policy as a Political Bargain, 73 ANTITRUST L.J. 483, 483-84 (2006); cf. Thurman Arnold, An Inquiry into the Monopoly Issue, N.Y. TIMes, Aug. 2 I, I938, at B I (arguing that a competitive economy on the model of Sweden can only be assured by more effective antitrust enforcement; otherwise the inflexible price structures and restraints of trade adopted by large industrial organizations can only be remedied by increased state control of industry on the model of the highly centralized industrial states developed in Germany or Italy).

49 The National Industrial Recovery Act, enacted in June 1933, effectively gave every industry a license to cartelize. Three months before, in Appalachian Coals, Inc. v. United States, 288 U.S. 344 (I933), the Supreme Court rejected the government's attempt to enjoin a cartel among distressed coal producers.

50 Coverage of antitrust and monopolies by the New York Times during mid-r 938 indicated that the Roosevelt Administration saw antitrust enforcement as a priority, but did not suggest a drastic, immediate, deeply entrenched, and long-lasting policy change along the lines that Elhauge's theory would require. For example, a story published in the immediate wake of the speeches by Arnold and President Roosevelt highlighted by Elhauge described those addresses as reassuring to business:

Instead of demanding drastic legislation at this session and forecasting an immediate trust-busting campaign by the Department of Justice, Mr. Roosevelt asked soberly for 
the new antitrust era on anticompetitive conduct would likely have been deferred, making it implausible that this regulatory development would have had short-term macroeconomic consequences during I939 and $1940 .{ }^{51}$

Second, Elhauge's supposed identification of the short-term macroeconomic effects of antitrust enforcement rests heavily on his claim that the economy's overall price level declined during the I938-I94I recovery. ${ }^{52}$ If prices fell while economic growth was surprisingly strong, that would indeed suggest the economy received a positive supply-side macroeconomic economic shock,,$^{53}$ and increased antitrust enforcement could be one candidate source. ${ }^{54}$ But the overall price level did not actually decline during the I938-I94I recovery period; 55 it is better to describe it as not changing. ${ }^{56}$ Moreover, there is no puz-

sensible study before action and disclaimed any idea of crusading against business for headline purposes.

The night before this message was dispatched Assistant Attorney General Thurman Arnold, in charge of Sherman Act enforcement, made in New York a restrained, constructive forecast of policy which fits into the old liberal tradition and would have been generally satisfactory to Woodrow Wilson.

Arthur Krock, Business Reassurance is Gaining Momentum, N.Y. TIMEs, May I, I938, at 65. Four months later, after Congress had established the Temporary National Economic Committee (TNEC) to conduct the long-term study called for by President Roosevelt, and after Arnold had brought cases against major oil refiners, the dominant aluminum producer, and the American Medical Association, the New York Times reported that the leading corporations and trade associations that were the subjects of the TNEC inquiry were "not fearful of the effects of the study" and "confident of the soundness and legality of their methods." Companies Gather Data for Inquiry, N.Y. TIMEs, Aug. 3 I, I938, at 23.

51 Cf. Thomas Mayer \& Monojit Chatterji, Political Shocks and Investment: Some Evidence from the I930s, $45 \mathrm{~J}$. ECON. HIST. 9I3, 920-22 (I985) (finding that political shocks during the I930s did not affect the aggregate level of business investment).

52 In support of this claim, Elhauge cites François R. Velde, The Recession of $1937-A$ Cautionary Tale, ECON. PERSP., Fall 2009, at I6, 26, 29 fig. I3.

53 The macroeconomic literature on the $1938-194$ I recovery is mainly concerned with evaluating the effects of shocks to aggregate demand arising from a relaxation in fiscal and monetary policy during 1938. But the outcome of the I938 congressional elections (which replaced a heavily pro-New Deal Congress with one in which President Roosevelt could be blocked by a coalition of Republicans and Southern Democrats) has been proposed as a positive shock to aggregate supply that could have increased business investment during the recovery by enhancing business confidence. See Mayer \& Chatterji, supra note 5I, 918, 922. Elhauge does not seek to distinguish between this possibility and another possible supply shock he highlights, which is the shift in antitrust enforcement. (These alternatives are roughly contemporaneous with respect to explaining the evolution of macroeconomic variables between mid-I938 and I94 I, although the election took place several months after the mid-I938 antitrust events that Elhauge identifies as shifting business expectations.)

54 The reverse happened during the I970s. Higher oil prices (another type of supply-side shock) were one cause of the unhappy combination of inflation and slow growth.

55 It would not be surprising if increased antitrust enforcement mattered to prices in some industries, however.

56 Consumer prices fell by 2.I\% from the June I938 trough through August I939, recovered the entire lost ground in one month, and then held roughly constant until early I94I, when they began to rise. Wholesale prices exhibited the same pattern, although they declined more sharply 
zle about the late r 930 s price level to resolve by postulating a positive shock to aggregate supply: the evolution of economy-wide prices during the I930s, including the late-I930s recovery period, is well explained without reference to post-I 937 antitrust enforcement. ${ }^{57}$

I do not dispute Elhauge's view that market power and antitrust can have large effects on overall economic performance. But I do not think that the evidence he marshals is sufficient to demonstrate the stronger claim he makes for a direct connection close in time between increased antitrust enforcement and macroeconomic outcomes.

\section{ANTITRUST ENFORCEMENT AND OVERLAPPING FINANCIAL INVESTOR OWNERSHIP}

When he turns to remedy, Elhauge argues that substantial overlapping financial investor ownership violates the Clayton Act, a centuryold antitrust statute that addresses mergers, joint ventures, and asset or stock acquisitions. ${ }^{58}$ His main concerns are to explain why the statute's exemption for passive investment does not insulate diversified financial institutions with shareholdings in horizontal rivals from liability, why the filing exemption for passive investment in the premerger notification process set up pursuant to the Hart-Scott-Rodino Antitrust Improvements $\mathrm{Act}^{59}$ is no bar to a Clayton Act suit, and why the statute of limitations for private damage actions does not necessarily prevent challenges to stock acquisitions made more than four years in the past. ${ }^{60}$

Elhauge does not discuss a range of problems that could make successful Clayton Act enforcement more difficult than he supposes. In

than consumer prices from June I938 through August I939 (losing 4.4\%) and began to rise slowly in late 1940 . I computed these percentages from the following data series downloaded from Federal Reserve Economic Data (FRED), https://research.stlouisfed.org/fredz [http://perma.cc/XFR5LWDK]: Consumer Price Index for All Urban Consumers: All Items (CPIAUCNS); Producer Price Index for All Commodities (PPIACO). Professor François Velde argues that the wholesale price series is more reliable, because of interpolations in the consumer price data. Velde, supra note $5_{2}^{2}$, at 26 . The five price measures depicted by Velde, id. at 29 fig. I3, which include these two data series, generally show prices falling from the recession's trough through mid-r 939 , and recovering the lost ground by the end of 1940 .

57 See Christina D. Romer, Why Did Prices Rise in the I930s?, 59 J. ECON. HIST. I67, I92 tbl.7 (I999) (presenting the results of an empirical study relating inflation rates to the extent of the shortfall in aggregate output relative to a full employment economy, rates of nationwide economic growth, and the distortionary legacy of the National Industrial Recovery Act).

58 Elhauge indicates that the anticompetitive effects of overlapping financial investor ownership could also be reached under Sherman Act section I and Federal Trade Commission Act section 5 , but that there would be no need to pursue these legal theories given the availability of Clayton Act section 7 .

59 Pub. L. No. 94-435, go Stat. I383 (I976).

${ }^{60}$ Elhauge also argues that his antitrust theory does not necessarily make mutual funds designed to track broad stock market indexes illegal. 
his view, antitrust enforcement would be straightforward: a federal antitrust enforcement agency, state government, or private plaintiff would meet its burden of production by demonstrating that the overlapping financial investor shareholdings lead to high and increasing market concentration, using a metric similar or identical to the one employed by Azar, Schmalz, and Tecu in their airline research. The defendant financial firms would be unable to meet their burden of production in response, according to Elhauge, because overlapping financial investor ownership creates no integrative efficiencies. ${ }^{61}$ As a result, any overlapping shareholdings sufficiently great to satisfy the plaintiff's initial burden would be summarily condemned, without need for the plaintiff to demonstrate that prices rose. ${ }^{62}$

Under Elhauge's analysis, competitive overlapping shareholdings would create a rebuttable presumption of competitive harm, but the presumption would likely be nearly irrebuttable in practice. In consequence, only a few lawsuits would be necessary. Institutional investors would quickly come to recognize the likelihood of this outcome and would solve the problem by divesting substantial overlapping shareholdings or committing not to vote their shares. ${ }^{63}$ This approach could work. But whether it would do so quickly is uncertain for a number of reasons that Elhauge does not address.

\footnotetext{
61 A defendant could also argue that the plaintiff's demonstration of substantial overlapping financial investor ownership is insufficient to satisfy the plaintiff's burden of production to show competitive harm, for example because the overlapping shareholdings do not involve firms that are rivals, or the prospect of entry would prevent competitive problems. Elhauge does not discuss such possibilities, most likely because he does not expect defendants to succeed frequently on bases like these.

62 Although Elhauge encourages public and private enforcers not to bring cases unless the overlapping financial investor ownership can be shown to have raised prices, he reads the Azar, Schmalz and Tecu study as indicating that a substantial increase in a concentration index that accounts for investor shareholdings for firms in a concentrated market implies a substantial lessening of competition, suggesting that he believes such proof would satisfy the plaintiff's burden of production. If, instead, plaintiffs also were required to produce an econometric study comparable to the Azar, Schmalz and Tecu research for each industry where overlapping financial investor ownership is challenged in order to satisfy their initial burden, many cases would not succeed even if competition was harmed. One problem is econometric identification. The airline study exploited differences in the extent of overlapping financial investor ownership between markets and over time to identify the consequences of that phenomenon. To the same end, the banking study exploited differences in overlapping financial investor ownership resulting from the exogenous growth in index funds (which caused financial investors to increase stock purchases of firms included in major equity indices but not to purchase the shares of some other firms with which the firms composing indices compete). These or other identification strategies may not be available when studying other industries

63 Whether the latter remedy would solve the problem depends on the mechanism by which overlapping financial investor ownership leads to anticompetitive outcomes. Committing not to vote shares would also potentially create agency problems by insulating managers from shareholder influence.
} 
First, enforcers and courts may be unwilling to conclude that competition will be harmed if the financial investor defendants can show that the exercise of market power in those businesses would harm other investments in their portfolios, such as their ownership stakes in suppliers, purchasers, or sellers of complementary products. ${ }^{64}$ The greater those investments, the less likely that the financial investors would benefit overall if the rival firms in which they invest compete less aggressively. It then becomes less likely that overlapping financial investor ownership in horizontal rivals will harm competition. ${ }^{65}$

Second, the potential breadth of the shareholdings prohibition may make enforcers and courts cautious, even when overlapping financial ownership is likely to harm competition. Under Elhauge's approach, overlapping financial ownership may violate the Clayton Act when industrial firms with common financial investors compete head-to-head only in markets that amount to a small portion of the business of each. ${ }^{66}$ For example, if Coca-Cola bought or built a brewery, it could be illegal for financial investors to purchase substantial shares in both Coke and SABMiller, an international brewing firm that owns the Miller brand. ${ }^{67}$ If overlapping financial investor ownership of Coke

64 This discussion ignores the possibility that overlapping financial investor ownership in vertically related firms could reduce competition among the horizontal rivals in which the financial investors also have ownership stakes. Horizontal competition could be lessened if (upstream) suppliers raise input prices (or limit input sales) to horizontal rivals without overlapping financial investor ownership, or if (downstream) customers restrict their purchases from horizontal rivals without overlapping financial investor ownership. But the greater the financial investors' aggregate ownership stake in vertically related firms (upstream or downstream from those with overlapping financial investor ownership), the more likely those investors would benefit if the horizontal rivals compete aggressively, and, thus, the more likely that the vertically related firms they own would not act to exclude horizontal rivals that do not have substantial overlapping financial investor ownership.

65 Under such circumstances, a court may question whether it is appropriate to infer competitive harm from a proposed measure of overlapping financial investor ownership similar to the measure employed in the Azar, Schmalz, and Tecu study. In theory, the measure could be modified to account for a broader range of financial interests. But it will be difficult to do so in practice because that adjustment would require a great deal of information about the businesses involved. For example, suppose the concern is with overlapping financial investor ownership interests in hospital chains that compete head-to-head in some cities. If the financial investors also own equity stakes in health insurers, it would be necessary to assess quantitatively the consequences of higher hospital services prices for hospital profits (which would rise) and for insurer profits (which would fall) in order to work out whether the financial investors would benefit on net from reduced competition in hospital services given their relative ownership stakes in the hospital and the insurer.

66 From the point of view of a financial investor, the products of a firm in which it owns shares and the geographic regions within which that firm sells are inextricably linked. A financial investor cannot ask a firm to divest any of its products or to decline to compete in any region in order to prevent head-to-head competition, even if the only head-to-head competition involves a product or region accounting for a small portion of firm revenues or profits.

67 Overlapping financial ownership of rival breweries would give Coke and SABMiller an incentive to compete less aggressively in beer regardless of how many other businesses those two 
and SABMiller violates the Clayton Act, moreover, financial investors owning Coke shares may also be barred from acquiring shares in Altria, a tobacco firm with a substantial ownership stake in SABMiller.

Third, it may be impossible in practice to attack some harms to competition from overlapping financial ownership under Elhauge's approach. Suppose overlapping financial investor ownership harms competition in some markets by discouraging firms from entering markets that are important to other firms in which their financial investors also have a stake. This possibility is not hypothetical: for example, the Justice Department identified similar conduct among the major airlines. ${ }^{68}$ Yet the absence of current head-to-head competition may prevent the plaintiff from establishing that overlapping financial investor ownership has generated an increase in concentration sufficient to meet the plaintiff's initial burden. Even when one or both firms have some assets that could be used to enter the other firm's markets, demonstrating that their potential rivalry would constrain prices absent overlapping financial investor ownership would often be challenging. ${ }^{69}$

Fourth, overlapping financial ownership created by diverse acquisitions by industrial firms may be insulated from effective antitrust challenges under Elhauge's theory. Suppose that financial investors do not alter the stock holdings in their portfolios, but that one of the industrial firms held in the portfolios of many financial investors acquires a new business previously owned by a different set of investors (as might be plausible if the acquired firm had been privately held). For example, suppose that Ford was privately held, then acquired by Microsoft. Competition in automobiles could be lessened if that business acquisition places Microsoft in head-to-head competition with another firm also in the portfolios of those financial investors, such as General Motors. But the overlapping financial investor interests would be insulated from antitrust attack under the Clayton Act because the financial investors did not acquire new equity stakes; there would be no

firms own. The brewery owned by Coke would need to have a large enough presence in the beer market for the overlap in financial investor ownership of firms that compete in brewing to avoid falling within the safe harbor that Elhauge proposes, which is based on a measure of concentration that accounts for financial investor shareholdings.

68 See Proposed Final Judgment and Competitive Impact Statement, United States v. Airline Tariff Publ'g Co., 59 Fed. Reg. I5,225 (Mar. 3 I, I994).

69 See Jonathan B. Baker, Sector-Specific Competition Enforcement at the FCC, 66 N.Y.U. ANN. SURV. AM. L. 4I3, 4I8-20 (20II) (explaining that the Justice Department's decision not to challenge a 1997 merger between adjoining local telephone providers not in direct competition was likely colored by the difficulty it would have faced in proving a potential competition case in court); $f f$. C. Scott Hemphill \& Tim Wu, Parallel Exclusion, I2 2 YALE L.J. I I82 (20I3) (discussing doctrinal routes for challenging parallel exclusion). 
stock acquisition to challenge. ${ }^{70}$ It is possible that the adverse consequences of overlapping financial investor shareholdings in Microsoft and General Motors could instead be reached under Sherman Act section I, however. ${ }^{71}$

Fifth, three efficiency defenses proffered by financial investor defendants may give enforcers and courts pause, at least as a matter of first impression. ${ }^{72}$ The benefits to capital markets on which these defenses are predicated - improved corporate governance, greater diversification, and enhanced financial market liquidity - are widely recognized by financial economists as important to the overall economy. But, as discussed below, these benefits may not hold up if proffered as the bases of defenses in antitrust litigation about overlapping financial investor ownership.

To begin with, financial firm defendants may claim that overlapping financial investor ownership creates efficiencies by improving corporate governance. As the defendants may point out, overlapping financial investor ownership may increase the number of investors with substantial financial stakes in each industrial firm. If some large financial investors are more willing than others to undertake active monitoring of managerial decisions (for example, through investor communication with firm management or investor voting of equity interests) ${ }^{73}$ in order to raise the value of the financial investors' equity investments, then overlapping financial investor ownership would increase the pressure on the managers of industrial firms to maximize shareholder value through cost-cutting or the pursuit of other operational efficiencies.

This corporate governance defense may get a hearing, but it is unlikely to be persuasive. Although a prohibition on overlapping financial investor ownership would be expected to reduce the number of large financial investors owning the shares of any given industrial firm, the remaining large investors, at first approximation, would each be expected to own substantially more shares than before (with little change in the total value of the firm's equity held by large financial

\footnotetext{
70 If the financial investor later increased its stake in Microsoft or General Motors, however, it is possible that those share purchases could be challenged under the Clayton Act.

71 In theory, Microsoft's acquisition of Ford could also be challenged on the ground that overlapping financial investor ownership is likely to facilitate tacit collusion in automobiles, but it would be difficult to prove that case.

72 Another possible defense, the claim that overlapping shareholdings are beneficial simply because they increase shareholder value, should not concern enforcers and courts. The antitrust laws do not permit firms to justify anticompetitive conduct on the ground that the exercise of market power increases firm profits.

73 Corporate governance benefits would likely be predicated on the active management of investments by the large financial investors.
} 
investors). ${ }^{74}$ With larger ownership stakes, each of the remaining investors would have a greater incentive than before to monitor firm management, so corporate governance would more likely improve overall, contrary to what defendants might contend. ${ }^{75}$

Financial defendants may raise another efficiency defense involving capital market benefits: they may claim that overlapping financial investor ownership improves the functioning of capital markets and encourages investment by making diversification less difficult or less expensive for investors. Financial investors benefit from owning stock in multiple airlines, for example, because they bear lower undiversifiable, firm-specific risks in their portfolios relative to those that they would bear if limited to owning stock in only one airline. ${ }^{76}$ The airlines and airline passengers arguably benefit too: the ability of financial inves-

74 Suppose that the economy has just four industrial firms, each with the identical market value: two airlines, Delta and United, and two automobile manufacturers, Ford and GM. Suppose further that there are only two large financial investors, Fidelity and Vanguard, with identically sized equity portfolios, and that each of those investors owns stock of the identical market value in each of the four industrial firms. If each financial investor is required to sell shares in one airline and one automaker, each would be expected, as a first approximation, to reinvest the funds such that it ends up holding shares in one airline and one automaker with double the previous market value. If so, financial ownership of each industrial firm would be more concentrated (the firm would have fewer large financial investors, each with greater shareholdings than before), but the value of its equity owned by financial investors would not change. Similarly, in an economy with many industrial firms and many financial investors, the equity reallocations that would follow a prohibition on overlapping financial investor ownership would, as an initial matter, likely concentrate industrial firm shareholdings, without necessarily leading to substantial change in the total value of each industrial firm's equity held by financial investors overall. This partial equilibrium analysis is a first approximation because it does not take into account the possibility, discussed below in connection with diversification, that a prohibition on overlapping financial ownership would affect the way that the individuals or entities that invest through large financial firms such as Fidelity and Vanguard would choose to diversify their portfolios. If large financial firms grow smaller as a result, then the largest financial investors in industrial firms could have lower stakes than before.

75 For corporate governance to be harmed by the concentration of a given value of equity ownership in the hands of fewer investors, one would have to suppose that industrial firms respond better to the interests of multiple smaller investors than to the interests of fewer larger investors (holding constant the total equity interest of large investors), or that a large financial investor would not become more active and influential if its equity ownership in an industrial firm grew substantially beyond its existing level. With respect to the former possibility, there may not be a simple relationship between the number of investors owning substantial blocks of shares and effective corporate governance. See Alex Edmans \& Gustavo Manso, Governance Through Trading and Intervention: A Theory of Multiple Blockholders, 24 REV. FIN. STUD. 2395 (20II) (indicating that a greater number of blockholders reduces shareholder monitoring of management but increases the responsiveness of share prices to what investors know about managerial effort). With respect to the possibility that large financial investors do not become more active as their equity ownership increases, it is likely that the corporate governance benefits of concentrating equity ownership in fewer hands would eventually experience diminishing returns as investors increase their ownership stakes, but equity ownership levels may not yet have reached that point.

${ }^{76}$ Investors value risk reduction, so they benefit from owning shares in multiple airlines. This is presumably why some investors purchase airline sector-specific mutual funds rather than stock shares in an individual airline. 
tors to diversify risks by holding shares in multiple airlines would tend to lower the cost of capital to airlines and increase airline investment. ${ }^{77}$ But the diversification benefits to the defendant financial investors of holding shares in two competing air carriers are limited, because airline profits and equity values are to a substantial extent the products of industry-wide trends, ${ }^{78}$ and because the defendant financial investors may be able to diversify their portfolios comparably by holding shares in other industrial firms. ${ }^{79}$

The diversification defense also supposes implicitly that the individuals, institutions (such as pension funds), and firms that invest through the large financial institutions (such as BlackRock or Fidelity) that are the likely antitrust defendants have no inexpensive alternative in order to achieve the benefits of portfolio diversification. Yet if overlapping financial investor ownership of competing industrial firms were prohibited, whether for a specific industry or overall, and if an individual financial institution could not diversify its portfolio to the same extent as before, the individuals and firms that now invest through the funds offered by defendant financial institutions could diversify their portfolios in other ways, such as by investing in multiple mutual funds or purchasing shares in multiple exchange-traded funds. ${ }^{80}$ I doubt that the resulting reallocation of financial investments would make much difference to the costs to industrial firms of raising capital by issuing equity. ${ }^{81}$ Even if antitrust enforcement leads

77 If financial ownership of multiple airlines is prohibited, financial investors would need to be compensated for bearing greater undiversifiable, firm-specific risks, so airline share prices associated with a given stream of expected profits or dividends would be lower, and the costs to airlines of raising capital by issuing equity would be higher.

78 If so, changes in the profits and equity values of competing firms would have a high positive correlation. (The diversification benefits of holding shares in different firms depend on the correlation of changes in their share prices. Those benefits are particularly great when equity values are negatively correlated.) On the other hand, competition or firm-specific shifts in cost and demand might lead to a negative correlation in the profits and stock prices of head-to-head rivals, increasing the diversification benefits to financial investors in owning shares in each. (Ironically, if overlapping financial investor ownership lessens competition, it could increase the positive correlation in profits across the firms, lessening those diversification benefits.) In addition, if the firms have multiple lines of business, firm profits and equity values could be negatively correlated for reasons having nothing to do with the profit streams of the competing businesses.

${ }_{79}$ For example, an airline's equity values may be positively correlated with those of hotel chains that serve its hub cities and thus would also profit from increases in demand for travel to those cities.

80 To this end, one would expect to see the development of independently owned index funds, perhaps sponsored by banks or insurance companies, each capped in size in order to prevent it from owning a sufficiently high share of the equity in competing industrial firms to trigger antitrust concerns but in aggregate large enough to serve index fund investors.

81 The resulting reallocation of financial investments would be expected to prevent the exercise of market power even if large investors owned shares in mutual funds investing in competing industrial firms so long as the managers of the industrial firms had no practical ability to identify the ultimate owners of mutual fund shares. 
to the divestiture of overlapping financial investor ownership in multiple industries, moreover, any capital market consequences may well be too diffuse to consider in antitrust litigation. ${ }^{82}$

Financial investors may offer a third efficiency defense by claiming that overlapping financial investor ownership increases liquidity in equity markets, thereby encouraging investment. The defendants may claim that their ability to own shares in multiple airlines, for example, means that equity transactions involving airline stocks will, on average, involve more financial investors buying and selling smaller shareholdings than would be observed if each financial investor was limited to owning stock in a single airline. ${ }^{83}$ Accordingly, by retaining the ability to own shares in multiple airlines, the equity markets for airline shares would be more liquid, as each smaller transaction would be expected to have a smaller effect on stock prices. ${ }^{84}$ As a result, defendants may say, overlapping financial investor ownership lowers the cost of capital for airlines. Again, I doubt that this possibility would make a practical difference to the airlines' cost of capital. In addition, any reallocation of investments that takes place as the individuals, institutions, and firms now investing through large financial firms like Fidelity and Vanguard work out new ways of diversifying their portfolios could reduce the average size of equity transactions, thereby restoring any lost liquidity and preventing a liquidity-related increase in the cost of capital for airlines. ${ }^{85}$

If capital market efficiencies are raised in a defense of overlapping financial investor ownership, a court would likely find the benefits within the relevant industry to be small relative to the anticompetitive harm. Any reduction in the airlines' costs of capital, for example, is unlikely to enhance those firms' ability to compete sufficiently to outweigh the competitive harms found by Azar, Schmalz, and Tecu: a $3 \%$ to $\mathrm{I} \%$ increase in airfares and a $6 \%$ reduction in the number of air-

\footnotetext{
82 See United States v. Phila. Nat'l Bank, 374 U.S. 32 I, 37 I (I963) (rejecting a claim that a merger would stimulate regional economic development and noting that an anticompetitive merger "is not saved because, on some ultimate reckoning of social or economic debits and credits, it may be deemed beneficial"). In evaluating horizontal mergers, the enforcement agencies do not consider efficiencies that are "vague, speculative, or otherwise cannot be verified by reasonable means," U.S. DEP'T OF JUSTICE \& FTC, HORIZONTAL MERGER GUIDELINES 30 (2010), and these agencies normally assess competition in each market independently, id. at $30 \mathrm{n}$. I4.

83 See supra note 74 .

84 If a financial investor wishes to purchase (or sell) a large stake in a short time, it will typically need to offer counterparties a premium (discount) relative to the price it would pay (receive) for a small equity transaction. Cf. Amir Rubin, Ownership Level, Ownership Concentration and Liquidity, Io J. FIN. MKTS. 2 I 9, 245 (2007) ("LL]iquidity tends to increase with institutional ownership levels" but it "tends to decrease with institutional concentration.").

85 As with diversification efficiencies, moreover, the capital market consequences of possible liquidity efficiencies may be too diffuse to consider in antitrust litigation.
} 
line passengers served. ${ }^{86}$ A court would be expected to give the financial investors an opportunity to make out these defenses, but I am skeptical that any would prevail.

Sixth, and finally, the empirical economic literature relating overlapping financial investor ownership to higher prices is in its infancy. Even if a court is persuaded by the existing empirical studies that suggest that overlapping financial investor ownership has led to substantially higher prices in the airline and banking industries, it may not be willing to conclude that the same outcome would occur in other industries without understanding the mechanism by which competition was harmed in airlines and banking. Without such an understanding, a court may not be willing to extrapolate the results from two industries onto a third, and may not be confident that it can frame an appropriate remedy. ${ }^{87}$ Under such circumstances, it may be unwilling to permit plaintiffs to satisfy their initial burden simply by demonstrating overlapping financial investor ownership. 88

Over time, these difficulties may be overcome. Some of these issues could be resolved through case-by-case adjudication. Addressing others may require additional economic research. But, in the meantime, some or all of these problems could make successful enforcement more difficult than Elhauge supposes.

86 Cf. U.S. DEP'T OF JUSTICE \& FTC, supra note 82, at 30-3 I (observing that, in reviewing horizontal mergers, the enforcement agencies "consider whether cognizable efficiencies likely would be sufficient to reverse the merger's potential to harm customers in the relevant market, e.g., by preventing price increases in that market").

87 Depending on the mechanism by which competition is harmed, it may be sufficient to prohibit financial investors in firms that compete head-to-head from communicating with management or exercising voting rights, or it may instead be necessary to restrict those investors to owning shares in only one firm in each industry.

88 In addition, the measure of overlapping financial investor ownership endorsed by Elhauge, which was used in Azar, Schmalz, and Tecu's airline study, is not identical to the measures relied upon by courts to assess concentration now (though it is a natural mathematical generalization of one common measure). Those authors chose a different measure for their banking study to address a limitation of the measure used in their airline study (generalizing their measure further to account for bank shareholdings in other banks). Moreover, as Professor Carl Shapiro pointed out in unpublished comments on the airline study, these measures may need further refinement to account for possible differences between the distribution of financial ownership and the distribution of financial control. Carl Shapiro, Univ. of Cal. Berkeley, Remarks at the Eighth Annual FTC Microeconomics Conference Discussing Anti-Competitive Effects of Common Ownership (Nov. I2, 2015). Until the research literature settles on a measure and shows that it is related to higher prices across multiple industries, it may be difficult for plaintiffs to rely on any specific measure to satisfy their initial burden of showing that overlapping financial ownership leads to substantially higher concentration in industries outside the industries that have been studied. 
Elhauge prefers case-by-case antitrust enforcement to legislative action, ${ }^{89}$ which he considers politically infeasible. ${ }^{90}$ He does not consider another alternative for addressing the market power concerns arising from overlapping financial investor ownership: the exercise of the Federal Trade Commission's dormant competition rulemaking power. ${ }^{91}$ This alternative is worth exploring given the potential problems with case-by-case antitrust enforcement. ${ }^{92}$

\section{CONCLUSION}

The economic research on which Elhauge's article is based adds to the contemporary indictment of the financial sector. Since I980, finance has diverted massive resources from other sectors of the economy without becoming more productive at its central task of financial intermediation..$^{93}$ The recent studies by Azar, Schmalz, and Tecu suggest that the concomitant growth in overlapping ownership of horizontal rivals by diversified financial institutions may facilitate anticompetitive conduct economy-wide.

Elhauge has successfully highlighted the potential significance of these market power problems and identified one possible way that antitrust enforcement could respond. His provocative suggestion that antitrust enforcement against overlapping financial ownership may transform the economy by lowering prices markedly, reducing inequality substantially, and increasing business investment could turn out to be correct, and the antitrust enforcement actions he proposes could succeed as remedies. If so, his article on horizontal shareholdings may appear prescient in retrospect.

89 See generally Eric Posner \& E. Glen Weyl, Mutual Funds' Dark Side, SLATE (Apr. I6, 2015, 9:46 AM), http://www.slate.com/articles/news_and_politics/view_from_chicago/20 I5/04/mutual _funds_make_air_travel_more_expensive_institutional_investors_reduce.html [http://perma.cc $\mathrm{N}_{4}$ ST-NCHY] (proposing a law directing employers to offer in retirement plans "only mutual funds that do not own a significant number of shares of more than one firm in a specific industry").

90 Elhauge also supposes that a statute could not practically exempt passive investments generating small overlapping financial investor shareholdings, and thus would be overinclusive.

91 See Jonathan B. Baker, Two Sherman Act Section I Dilemmas: Parallel Pricing, the Oligopoly Problem, and Contemporary Economic Theory, 38 ANTITRUst Bull. I43, 207-Ig (I993); C. Scott Hemphill, An Aggregate Approach to Antitrust: Using New Data and Rulemaking to Preserve Drug Competition, rog Colum. L. REv. 629, 673-82 (2009); Adam Speegle, Note, Antitrust Rulemaking as a Solution to Abuse of the Standard-Setting Process, i to MICH. L. REv. 847, 865 (20I2).

92 Competition rulemaking would also facilitate making an economy-wide comparison between the possible anticompetitive harms from overlapping financial investor ownership and the possible benefits of greater diversification and enhanced financial market liquidity.

93 See generally Thomas Philippon, Has the US Finance Industry Become Less Efficient? On the Theory and Measurement of Financial Intermediation, I05 AM. ECON. REV. I408 (2015). 